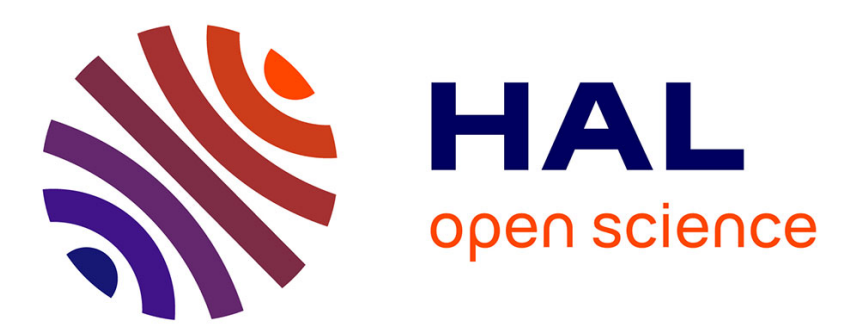

\title{
Monitoring water stress using time series of observed to unstressed surface temperature difference
}

Gilles Boulet, Ghani Chehbouni, P. Gentine, Benoît Duchemin, J. Ezzahar, R. Hadria

\section{- To cite this version:}

Gilles Boulet, Ghani Chehbouni, P. Gentine, Benoît Duchemin, J. Ezzahar, et al.. Monitoring water stress using time series of observed to unstressed surface temperature difference. Agricultural and Forest Meteorology, 2007, 146 (3-4), pp.159-172. 10.1016/j.agrformet.2007.05.012 . ird-00388858v2

\section{HAL Id: ird-00388858 \\ https://hal.ird.fr/ird-00388858v2}

Submitted on 27 May 2009

HAL is a multi-disciplinary open access archive for the deposit and dissemination of scientific research documents, whether they are published or not. The documents may come from teaching and research institutions in France or abroad, or from public or private research centers.
L'archive ouverte pluridisciplinaire HAL, est destinée au dépôt et à la diffusion de documents scientifiques de niveau recherche, publiés ou non, émanant des établissements d'enseignement et de recherche français ou étrangers, des laboratoires publics ou privés. 

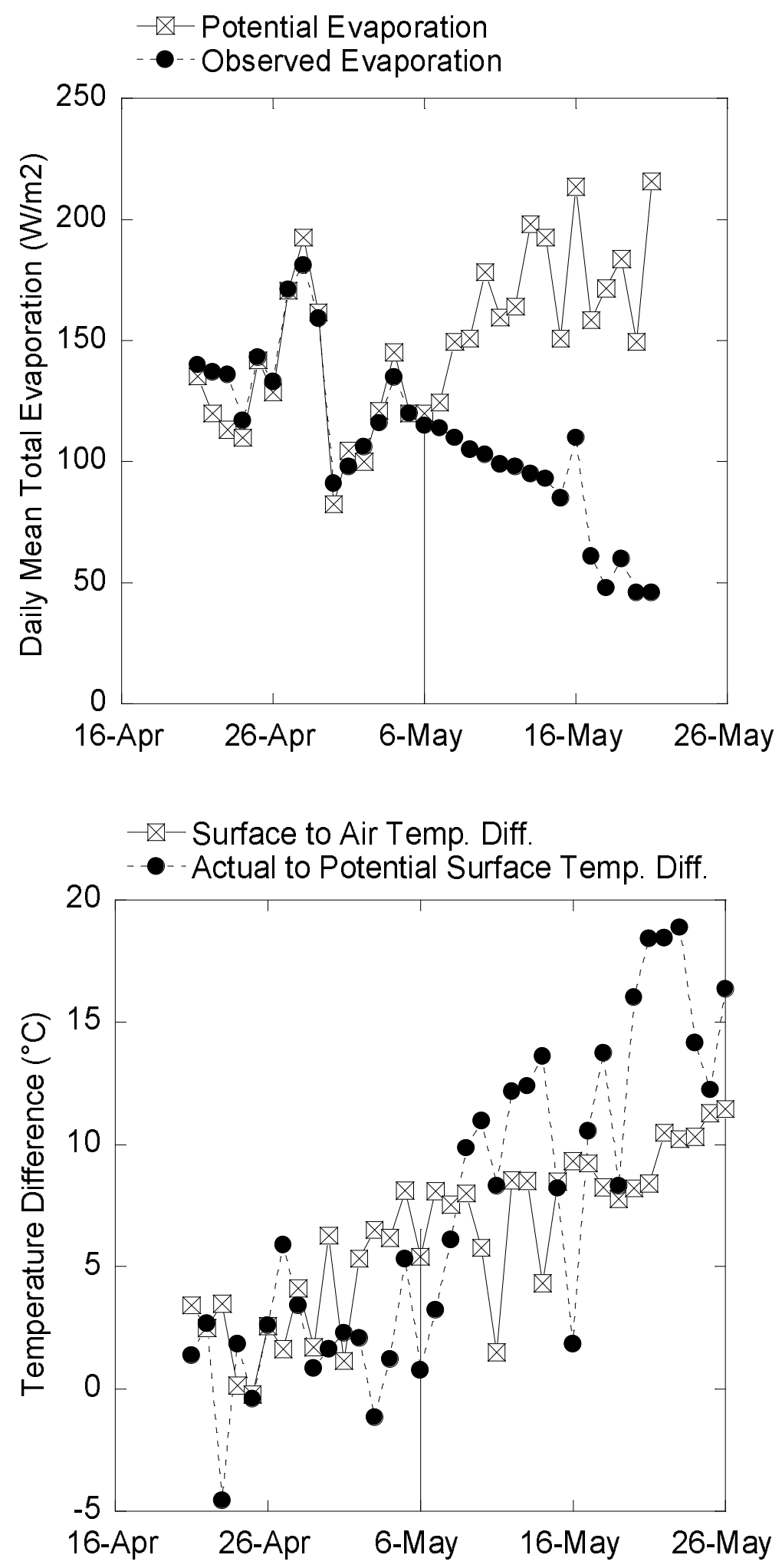

Figure 1a (top) and Figure 1b (bottom) 

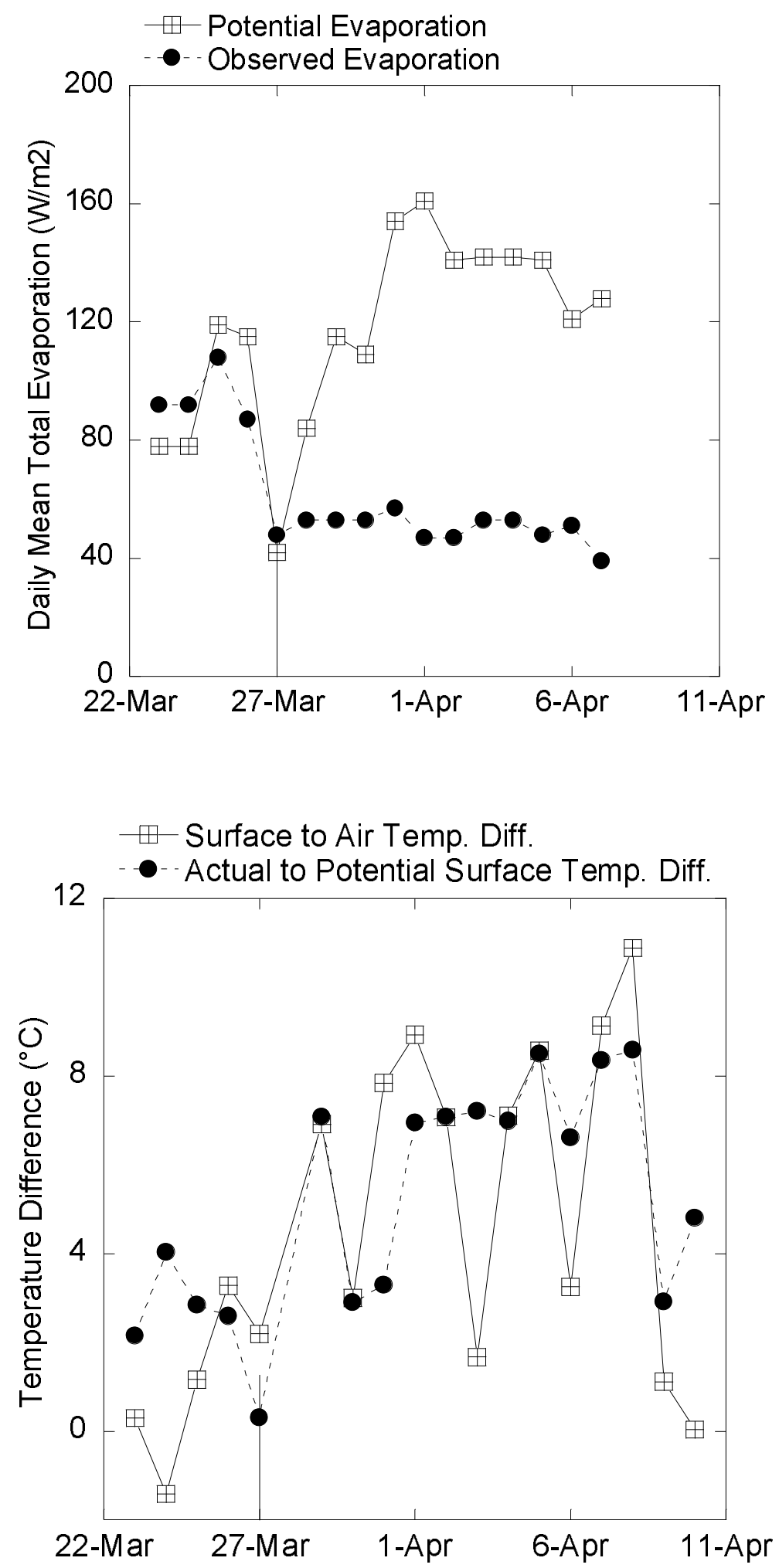

Figure $2 \mathrm{a}$ (top) and $2 \mathrm{~b}$ (bottom) 

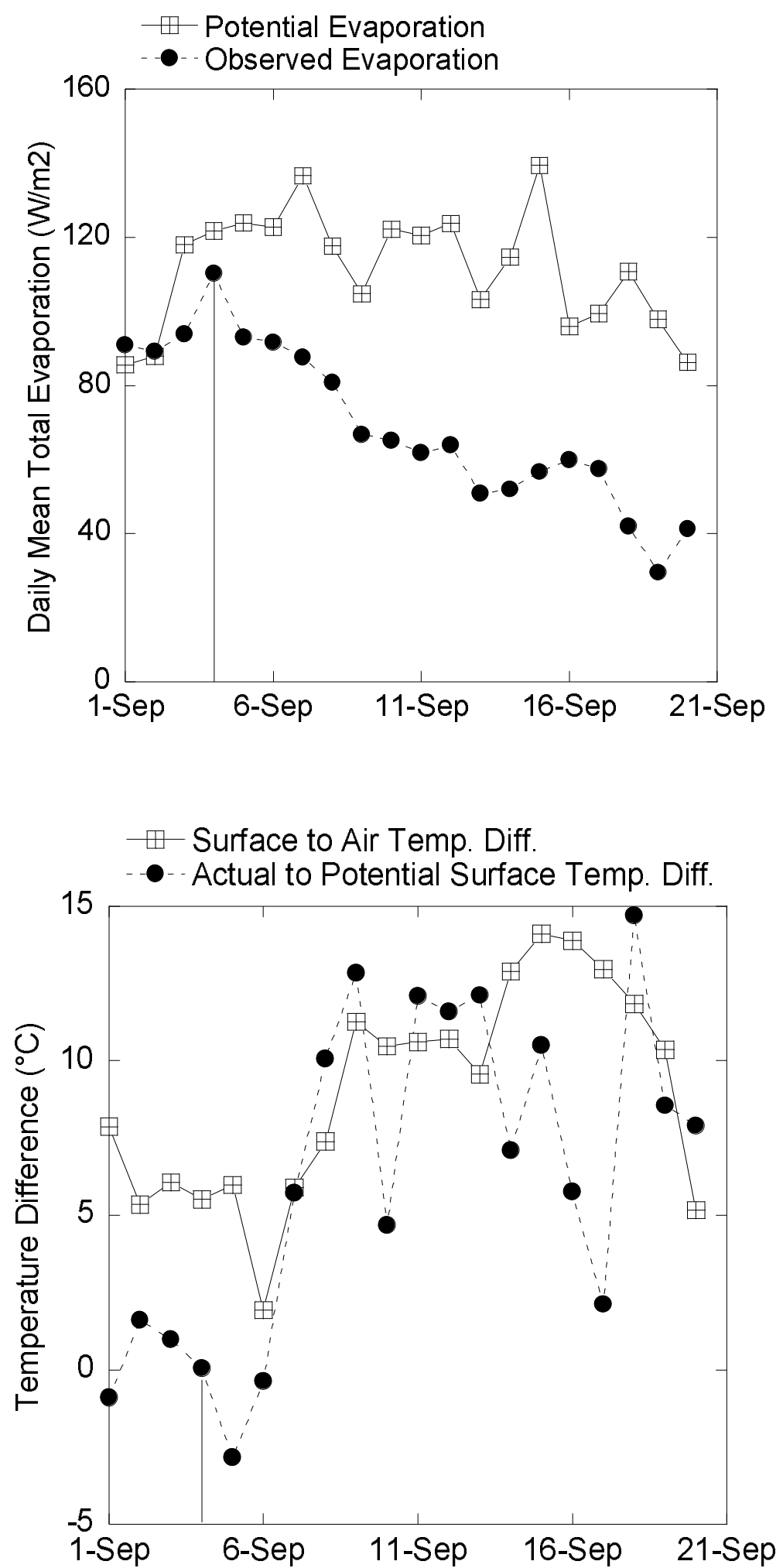

Figure 3a (top) and 3b (bottom). 


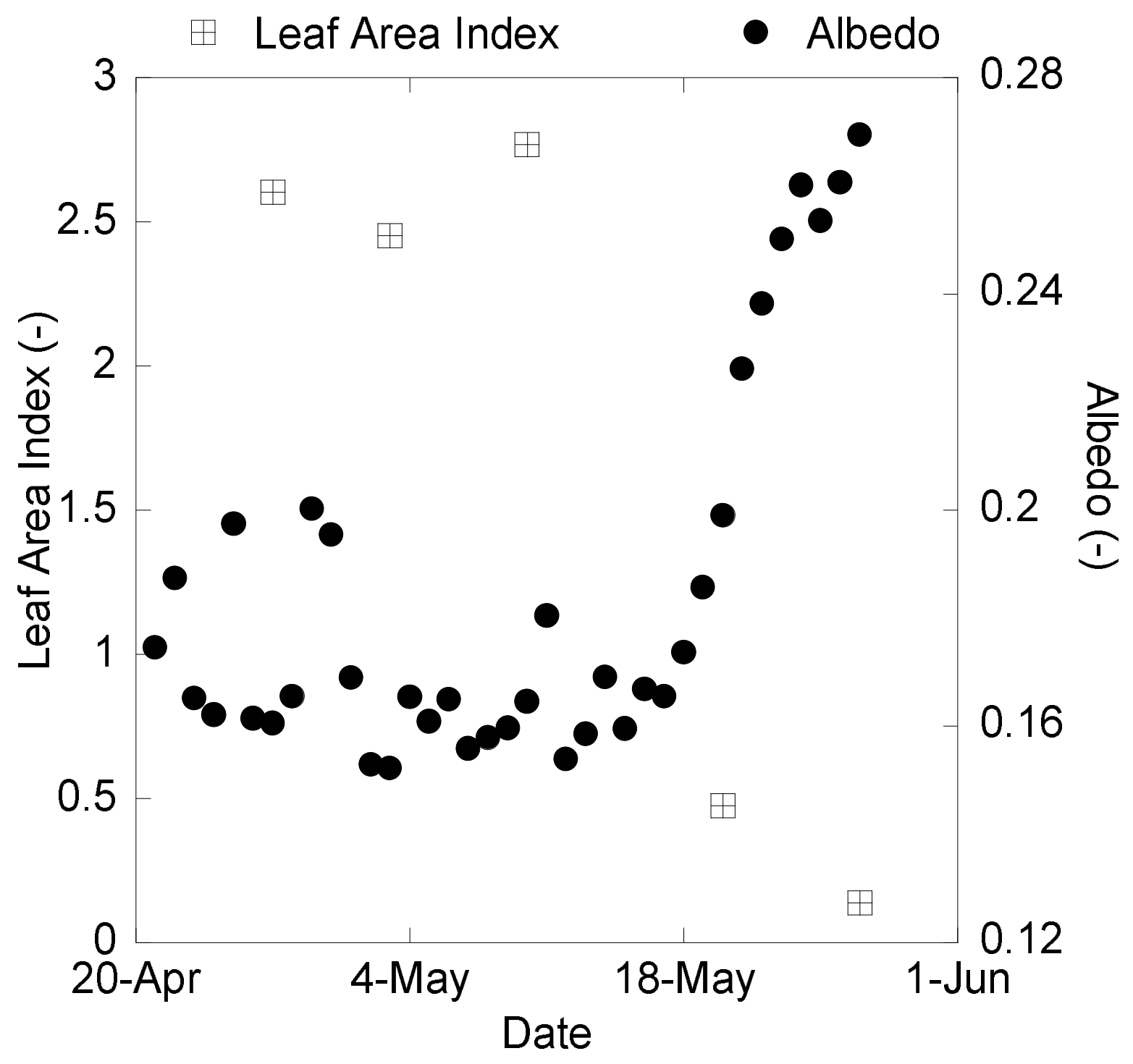

Figure 4 


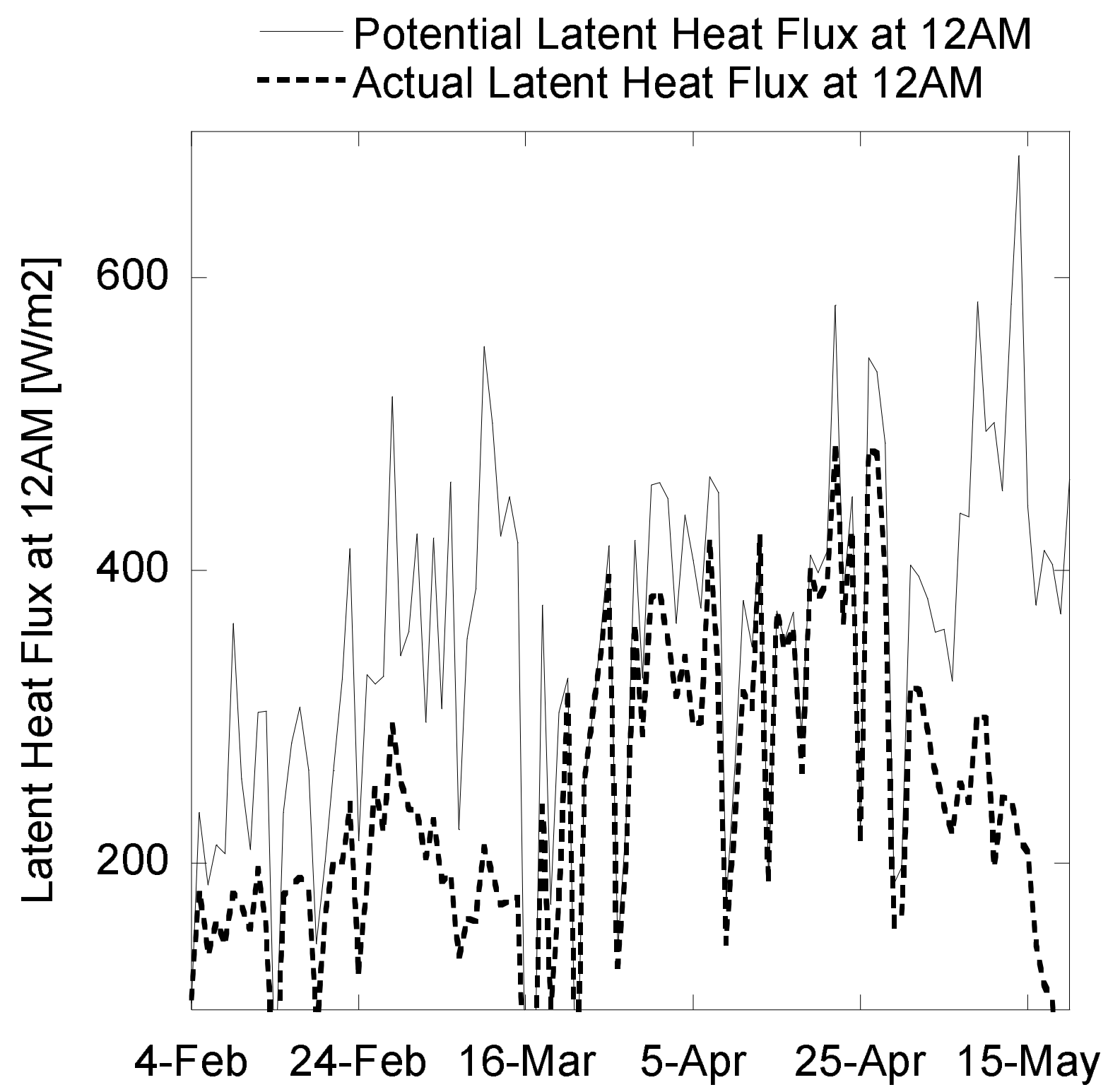

Figure 5 


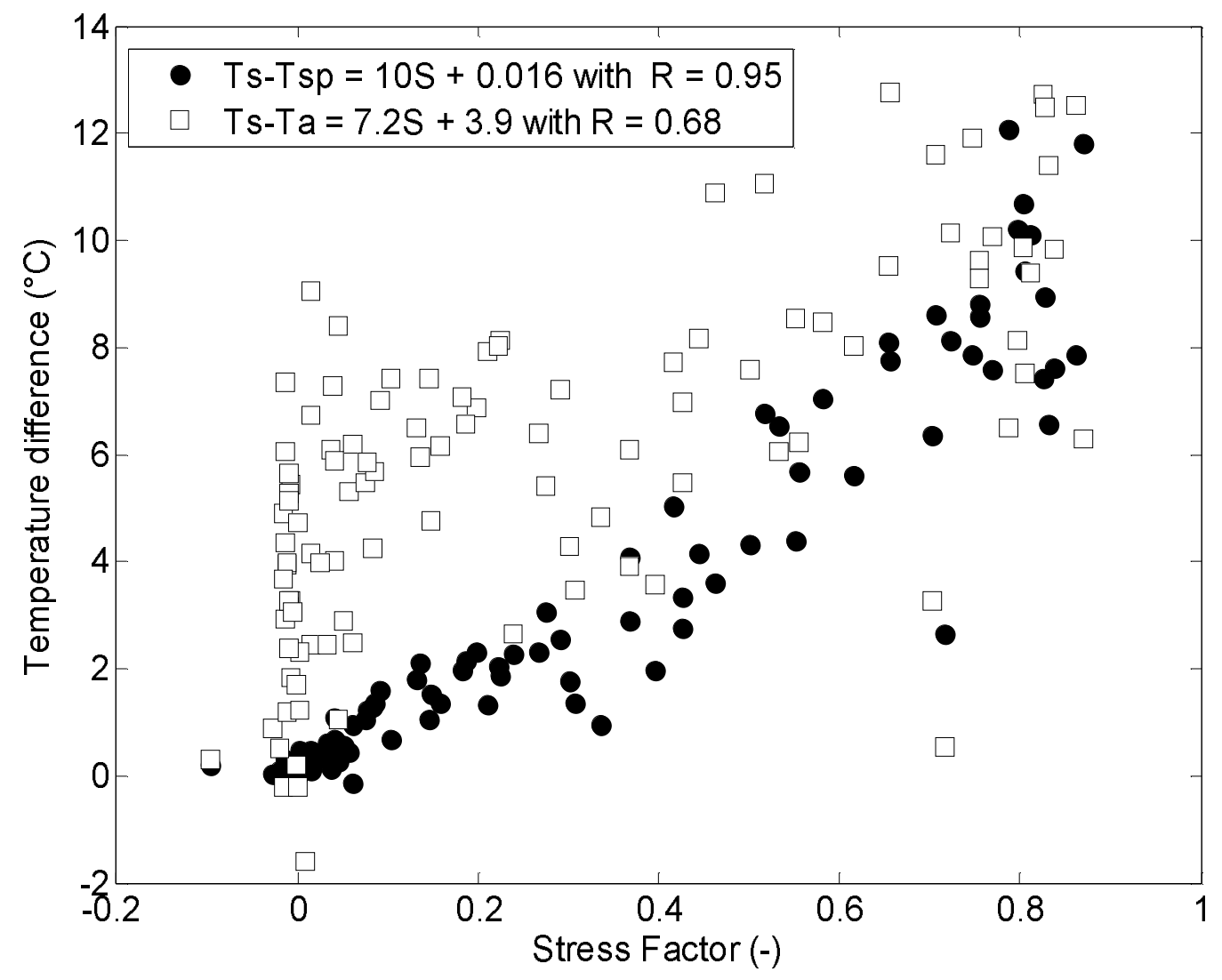

Figure 6 


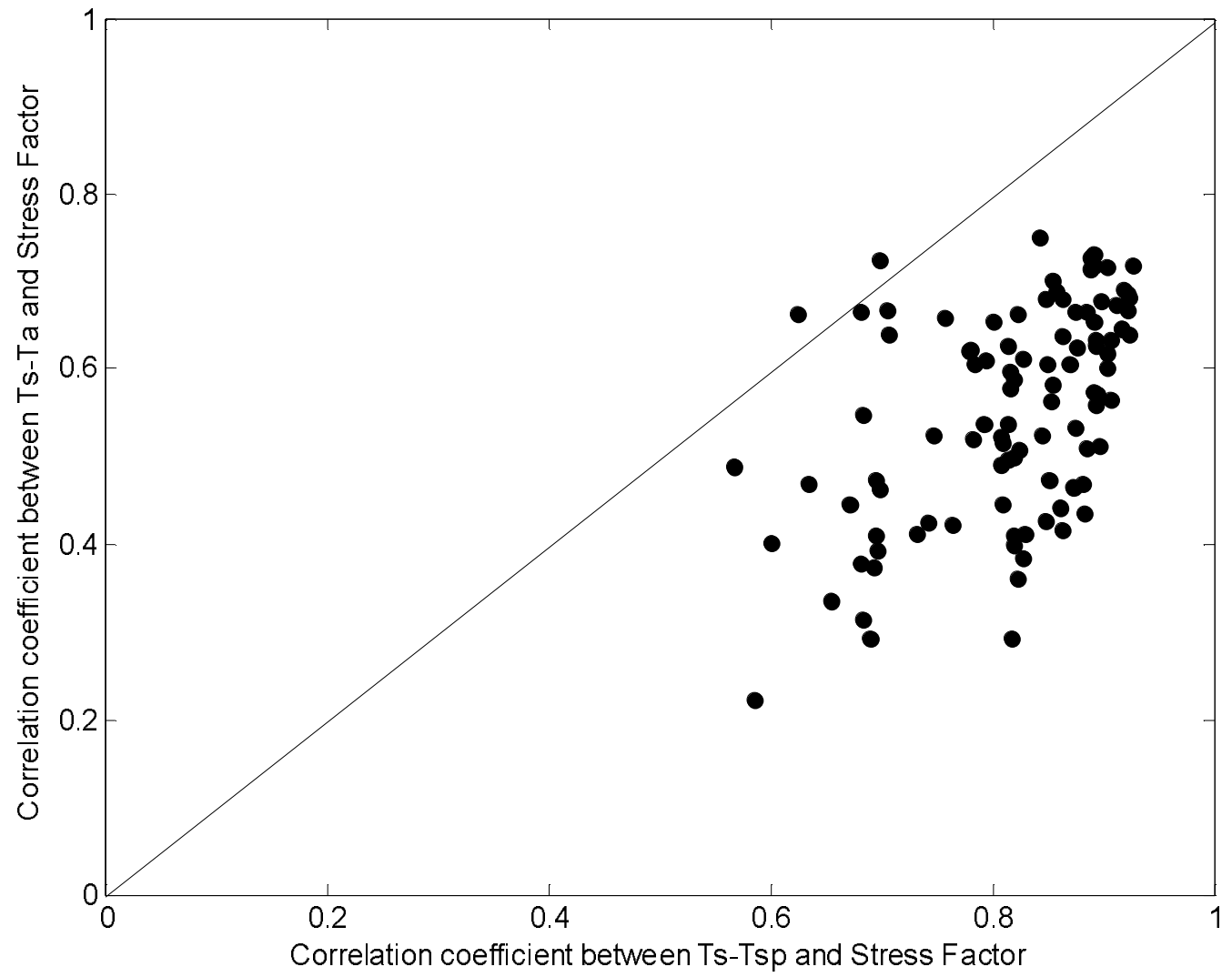

Figure 7 


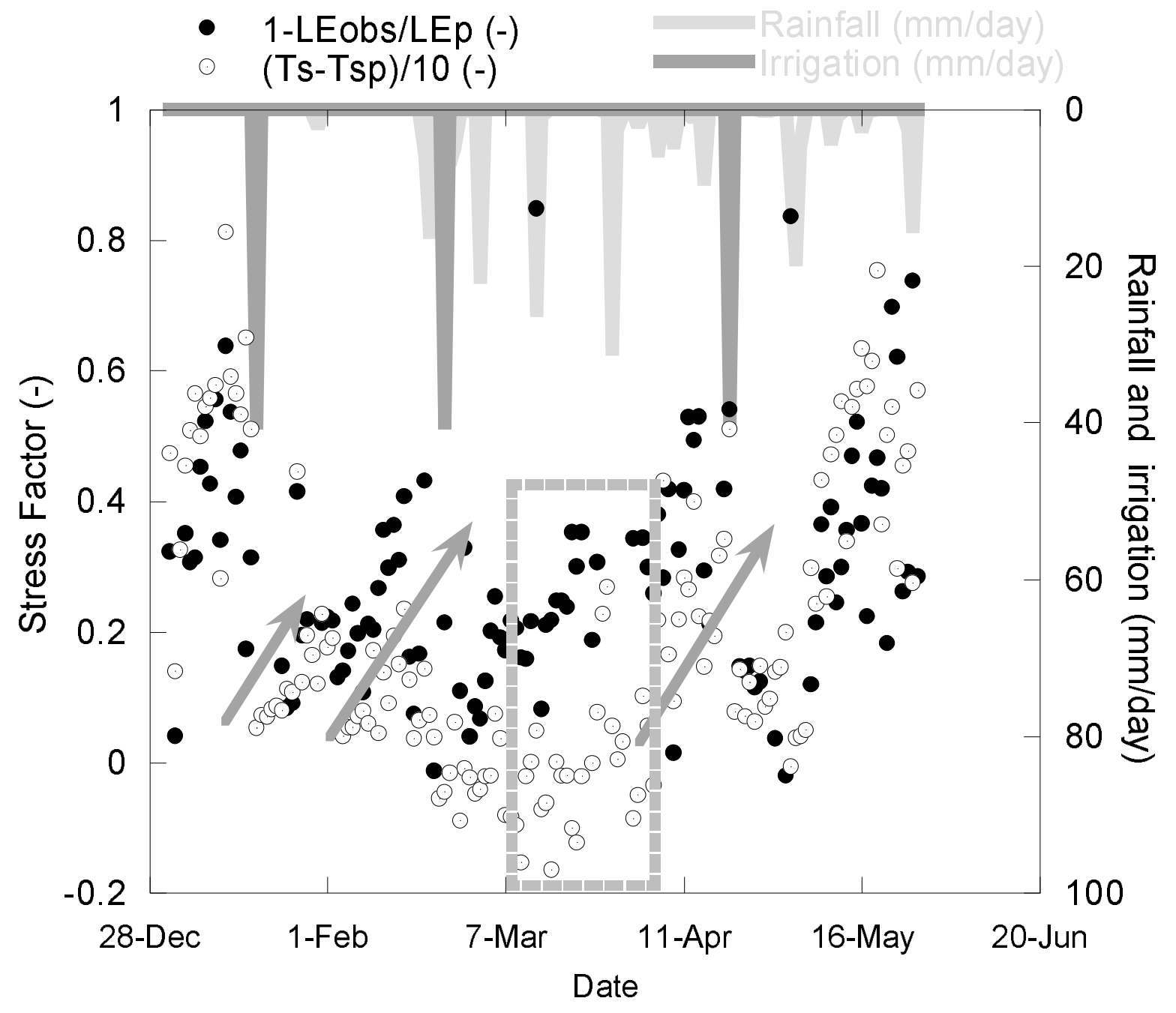

Figure 8 